\title{
Ottoman Legacies of the State: An Introduction
}

\section{Jonathan Endelman}

This collection of papers, from very different vantage points, makes the argument that the Ottoman Empire bequeathed significant legacies to the notion and practices of modern political governance in the Middle East. The three essays address the impact Ottoman policies had on territories that had once been part of the empire, focusing most closely on the development of state institutions, nationalism, and the position of the caliphate. By exploring these key issues, the authors hope to call attention to the importance of the Ottoman experience in laying the groundwork for future political life in the region.

Juan Cole in "Caliphates and Juntas: Ottoman Legacies in Today's Controversies over Religion and State in the Arab World" argues that modern-day Islamist groups such as ISIS and the Islamic States of Iraq and Syria are inspired more by the PanIslamism of Abdulhamid II (1876-1909) than by the Abbasid Caliphate. Although classically the Sunni religious establishment had not assumed a position of direct rule of the state, Abdulhamid capitalized upon the claim of the Ottoman Sultan to be simultaneously Caliph, or worldwide religious leader of all Muslims. At a time when the empire was suffering great setbacks in its foreign policy, Abdülhamid's claim to the caliphate was an attempt to acquire some measure of symbolic capital against the European powers that he saw encroaching upon the empire. Efforts to revive the caliphate after its abolition in 1923 by groups like ISIS and the Muslim Brotherhood attempt to highlight and "cash in on" the same anticolonial aspect used by Abdulhamid II.

Jonathan Endelman in his work "In the Shadow of Empire: States in an Ottoman System" argues that the origin of the Middle Eastern state should be placed further back in time than has generally been acknowledged to be the case. Although most scholars focus on the British and French colonial period in the aftermath of the Ottoman Empire's collapse in World War I as the beginning of the Middle Eastern state, starting in the mid-nineteenth century some parts of the Ottoman Empire began developing governmental functions that would serve as the basis for later polities. Focusing, on the one hand, on a state within the empire, Egypt, and, on the other, on the empire turning into a state, Turkey, he traces the evolution of statelike attributes in economic, administrative, and political arenas. He shows how the Ottoman Empire coexisted with states developing within it even as the empire came closer to resembling a state. This observation questions the sharp distinction made between state and empire, arguing that the two may coexist and interact with one another in complex ways.

Finally, Nader Sohrabi's "Reluctant Nationalists, Imperial Nation-State, and NewOttomanism: Turks, Albanians, and Antinomies of the End of Empire" begins with the question: Why did the Ottoman Empire collapse? Sohrabi contends that the key cause was a combination of geopolitical military defeats embodied in the Balkan Wars of 1912-13 combined with the hardening of ethnic boundaries between Turks and other constituent nationalities within the empire including Albanians, Macedonians, and Arabs. Sohrabi traces how both the leadership of the Committee of Union 
and Progress, later known as the Young Turks, as well as the incipient Albanian nationalist movement gradually became more weary of each other. As a result, the Albanians pushed for separatist nationalism as it became clear that Ottoman Imperial Centralization entailed Turkish ethnic homogenization for the non-Turkish areas of the empire. Sohrabi shows how initial demands for autonomy on the part of Albanians gradually grew more militant as the Young Turks became more intransigent in refusing them, culminating in the ultimate break and demand for full-fledged Middle Eastern independence during the Balkan Wars.

Studying the nineteenth-century Ottoman Empire gives us a window into the creation of nation-states and their operations in the aftermath of World War I. It enables modern observers to trace the development of social phenomena in these countries from their historical roots. Additionally, it enables analysts to more accurately judge the extent to which European colonial powers altered or left in place governance structures and policies in the region. In the wake of a resurgence of interest in the concept of empire, the late Ottoman Empire provides a unique opportunity to capture imperial structures mid-stream into the transition of becoming a series of nation-states. Only by examining the tensions inherent in this transition can we understand the resulting state entities that arose out of the ashes of empire and the legacies that they both rely upon and struggle against as they develop. 